\title{
Hypocholesterolaemic effect of water-insoluble fish protein from Alaska pollock in ovariectomised rats is not abolished by methionine addition
}

\author{
Masaki Kato ${ }^{1}$, Hiroshi Ogawa ${ }^{2}$, Taro Kishida ${ }^{1}$ and Kiyoshi Ebihara ${ }^{1 *}$ \\ ${ }^{1}$ Department of Biological Resources, Faculty of Agriculture, Ehime University, 3-5-7 Tarumi, Matsuyama 790-8566, Japan \\ ${ }^{2}$ Faculty of Human and Cultural Studies, Tezukayamagakuin University, 4-2-2 Harumidai, Minami-ku, Sakai-city, Osaka \\ 590-0113, Japan
}

(Received 16 August 2010 - Revised 8 December 2010 - Accepted 9 December 2010 - First published online 4 May 2011)

\section{Abstract}

The present study investigated whether the hypocholesterolaemic effect of water-insoluble fish protein (IFP) from Alaska pollock in ovariectomised (OVX) rats was affected by methionine (Met) addition. OVX rats (6 months old) were fed a cholesterol-free diet containing casein, IFP or IFP + Met as a protein source for $28 \mathrm{~d}$. The ratio of Met:glycine was lower in the IFP and IFP + Met diets compared with the casein diet. Body-weight gain, food intake and liver lipids were not affected by the diet. Plasma total cholesterol concentration was lower in OVX rats fed the IFP diet compared with those fed the casein diet. The hypocholesterolaemic effect of the IFP diet was not abolished by Met addition. Amount of bile acids in the small-intestinal content and faecal excretion of bile acids were higher in OVX rats fed the IFP and IFP + Met diets compared with those fed the casein diet. Ileal bile acid transporter (IBAT) mRNA level and faecal excretion of bile acids were significantly lower and higher, respectively, in OVX rats fed the IFP diet compared with those fed the casein diet, but not in those fed the IFP + Met diet. Thus, the hypocholesterolaemic effect of the IFP diet seems to be mediated by increased faecal excretion of bile acids coupled with decreased reabsorption of bile acids from the ileum through a decrease in IBAT and the change in cholesterol metabolism linked to the amino acid profile.

Key words: Bile acid: Methionine addition: Ovariectomised rats: Plasma cholesterol: Water-insoluble fish protein

It is well known that lipid metabolism is influenced by sex hormones in animals and humans ${ }^{(1,2)}$. Sex hormones, such as oestrogen, have a major impact on atherosclerotic processes, and studies in animal models have shown that oestrogen inhibits the development of atherosclerotic lesions ${ }^{(3,4)}$. Oestrogen deficiency is associated with changes in blood lipid levels. It is now clear that oestrogen deficiency plays a key pathogenetic role in the development of CHD in women, as supported by several epidemiological findings ${ }^{(5,6)}$. Oestrogen replacement therapy in postmenopausal women provides a protective effect against CHD. However, side effects such as breast cancer, resumption of menses and weight gain have consistently accompanied this treatment ${ }^{(7,8)}$.

The amount and type of dietary protein influences blood cholesterol concentrations. In general, animal proteins are considered to be hypercholesterolaemic when compared with plant proteins ${ }^{(9)}$. Fish consumption has been shown to be inversely associated with $\mathrm{CHD}^{(10)}$. In many clinical trials, the benefits of fish consumption have been attributed to the effects of fish oil; however, recent studies have reported hypocholesterolaemic effects of fish protein ${ }^{(11-14)}$. It is also known that individual amino acids are involved in the hypocholesterolaemic effects of dietary protein ${ }^{(15,16)}$. This concerns whether specific amino acid(s) of dietary proteins affect the metabolism of cholesterol either directly or indirectly after absorption. A potential explanation for the hypocholesterolaemic effect of soya protein when compared with casein lies in its amino acid profile, especially methionine, glycine, lysine and arginine. Sulphur-containing amino acids are recognised to be some of the most potent modulators of lipid metabolism among amino acids ${ }^{(17)}$. Methionine (Met) was shown to increase serum cholesterol concentration in rats fed a cholesterol-free $\operatorname{diet}^{(18)}$. Morita et al. $^{(19)}$ have reported that the hypocholesterolaemic effects of soya protein, potato protein and rice depended on their low Met content.

The water-insoluble fish protein (IFP) prepared by washing minced fish meat with water, a process that removes watersoluble proteins and fat, is a useful ingredient in processed sea foods, such as fish cakes (kamaboko), baked fish paste (chikuwa) and fish sausage in Japan. We reported that IFP from Alaska pollock (Theragra chalcogramma) meat had a hypocholesterolaemic effect in ovariectomised (OVX) rats $^{(20)}$.

Abbreviations: IBAT, ileal bile acid transporter; IFP, water-insoluble fish protein; Met, methionine; OVX, Ovariectomised rat; SREBP, sterol regulatory element-binding protein.

*Corresponding author: K. Ebihara, fax +81 899469847 , email ebihara@agr.ehime-u.ac.jp 
Table 1. Composition of the experimental diets

\begin{tabular}{lccc}
\hline & \multicolumn{3}{c}{ Diets $(\mathrm{g} / \mathrm{kg})$} \\
\cline { 2 - 4 } Ingredients & Casein & IFP & IFP + Met \\
\hline Casein & 200 & 197 & 197 \\
IFP* & - & 535 & 532.5 \\
Gelatinised maize starch & 532 & 100 & 100 \\
Sucrose & 100 & 70 & 70 \\
Soyabean oil & 70 & 35 & 35 \\
Mineral mixture† & 35 & 10 & 10 \\
Vitamin mixtureł & 10 & 50 & 50 \\
Cellulose§ & 50 & 3 & 3 \\
L-Cys & 3 & - & $2 \cdot 5$ \\
DL-Met & - & &
\end{tabular}

IFP, water-insoluble fish protein.

* SURIMI, prepared from Alaska pollock.

†Based on AIN-93G ${ }^{(21)}$.

¥The AIN-93 vitamin mixture used in the present study contained $20 \mathrm{~g}$ of choline bitartrate $/ 100 \mathrm{~g}$

§ PC200 (Danisco Japan Limited, Tokyo, Japan)

As with soya protein, IFP from Alaska pollock meat has a lower content of Met and a higher content of arginine compared with casein. Therefore, in the present study, we investigated whether the hypocholesterolaemic effect of IFP from Alaska pollock in OVX rats was affected by Met addition.

\section{Materials and methods}

\section{Materials}

IFP prepared from Alaska pollock ( $T$. chalcogramma) meat was donated by Nippon Suisan Kaisha Limited (Tokyo, Japan). IFP was prepared by washing minced Alaska pollock meat with water, a process that removes water-soluble proteins and fat. IFP was cut into small pieces, freeze-dried and powdered.

Acid-precipitated lactic casein (30 mesh) was purchased from New Zealand Dairy Board (Wellington, New Zealand)

The protein content of IFP and casein was determined by the Kjeldahl method, with an N-to-protein conversion factor of $6 \cdot 25$. The lipid content of IFP and casein was determined by the Soxhlet method. The protein content and lipid content of IFP and casein were 90.5 and $0.04 \mathrm{~g} / 100 \mathrm{~g}$, and 89.3 and $0 \cdot 12 \mathrm{~g} / 100 \mathrm{~g}$, respectively.

\section{Animals and diets}

The present study was approved by the Laboratory Animal Care Committee of Ehime University. Rats were maintained in accordance with the Guidelines for the Care and Use of Laboratory Animals of Ehime University.

Female Wistar rats (6 months old) were housed individually in screen-bottomed, stainless-steel cages in a room maintained at $23 \pm 1{ }^{\circ} \mathrm{C}$ with a $12 \mathrm{~h}$ light $-12 \mathrm{~h}$ dark cycle (light on 07.00-19.00 hours). Rats were acclimatised by feeding on a commercial solid diet $\left(\mathrm{MF}^{\circledR}\right.$; Oriental Yeast Company, Osaka, Japan) for $7 \mathrm{~d}$. After acclimatisation, rats were anaesthetised by intraperitoneal injection of sodium pentobarbital (30 mg/kg body, Nembutal; Abbott Laboratories, Chicago,
IL, USA), and bilaterally OVX. The rats were then fed a commercial solid diet $\left(\mathrm{MF}^{\circledR}\right.$; Oriental Yeast Company) during the $8 \mathrm{~d}$ recovery period, after which they were randomly divided into three groups ( $n$ 6), and allowed free access to one of the following diets for $28 \mathrm{~d}$ : casein, IFP or IFP + Met diet (Table 1) ${ }^{(21)}$. In the present study, rats fed the casein and IFP + Met diets received $5.0 \mathrm{~g} \mathrm{Met} / \mathrm{kg}$ diet, which was a sufficient amount of Met recommended for rodents $(4.9 \mathrm{~g}$ $\mathrm{Met} / \mathrm{kg}$ diet) by the National Research Council ${ }^{(22)}$. On the other hand, rats fed the IFP diet received $2.5 \mathrm{~g} \mathrm{Met} / \mathrm{kg}$ diet, which was half the amount of Met recommended for rodents by the National Research Council. For each rat, body weight and food intake were recorded daily in the morning before the food was replaced. The amino acid composition of the casein, IFP and IFP + Met diets was determined using an amino acid analyser (model JCL-555/V; Japan Electron Optics Laboratory Company Limited, Tokyo, Japan; Table 2) ${ }^{\text {(23) }}$

\section{Sampling and analytical procedures}

Before the rats were killed, faeces were collected from each rat over the final $3 \mathrm{~d}$ of the experimental period. The faeces were freeze-dried, weighed and milled. On the last day of the experimental period, a blood sample was collected at night (24.00-01.00 hours) from the neck of each rat into a blood collection tube (Vacutainer; Becton Dickinson, Franklin Lakes, NJ, USA) containing heparin as an anticoagulant without fasting. The plasma was separated by centrifugation at $1400 \mathrm{~g}$ at $4^{\circ} \mathrm{C}$ for $15 \mathrm{~min}$ and stored at $-50^{\circ} \mathrm{C}$ until analysis. After blood collection, the liver was immediately perfused with ice-cold saline $(9 \mathrm{~g} \mathrm{NaCl} / 1)$, removed, washed with cold saline, blotted dry on filter paper and weighed. After weighing, about $0.5 \mathrm{~g}$ of the liver was frozen immediately in liquid $\mathrm{N}_{2}$, and stored at $-80^{\circ} \mathrm{C}$ until RNA extraction. The remaining liver was stored at $-50^{\circ} \mathrm{C}$ until lipid analysis. After the liver

Table 2. Amino acid composition of the experimental diets $(n 3)^{\star}$

\begin{tabular}{lrrr}
\hline & \multicolumn{3}{c}{ Diets (g/kg diet) } \\
\cline { 2 - 4 } Amino acid & Casein & \multicolumn{1}{c}{ IFP } & IFP + Met \\
\cline { 2 - 4 } Tau & \multicolumn{1}{c}{ IFP } & 0.2 & 0.2 \\
Thr & 7.0 & 5.4 & 5.4 \\
Ser & 8.5 & 4.6 & 4.6 \\
Asp & 15.2 & 17.5 & 17.5 \\
Glu & 53.9 & 33.0 & 33.0 \\
Gly & 4.1 & 6.6 & 6.6 \\
Ala & 6.8 & 10.5 & 10.5 \\
Met & 5.0 & 2.5 & 5.0 \\
Cys & 0.8 & 1.0 & 1.0 \\
Val & 15.7 & 9.9 & 9.9 \\
Ile & 10.1 & 7.3 & 7.3 \\
Leu & 20.8 & 14.3 & 14.3 \\
Tyr & 12.6 & 3.4 & 3.4 \\
Phe & 11.2 & 6.2 & 6.2 \\
His & 4.8 & 2.5 & 2.5 \\
Lys & 20.8 & 20.4 & 20.4 \\
Arg & 7.7 & 10.2 & 10.2 \\
\hline
\end{tabular}

IFP, water-insoluble fish protein.

* Each value is the mean of three observations. 
had been removed, the small intestine was removed. The contents of the small intestine were transferred into a pre-weighed tube, freeze-dried and weighed. The middle $5 \mathrm{~cm}$ of the terminal $25 \mathrm{~cm}$ of the small intestine was flushed with ice-cold saline, frozen in liquid $\mathrm{N}_{2}$ and stored at $-80^{\circ} \mathrm{C}$ until RNA extraction.

\section{Biochemical analysis}

The concentration of total cholesterol and TAG in the plasma was determined enzymatically using commercial diagnostic kits (Cholesterol E-Test Wako and Triglyceride E-Test Wako; Wako Pure Chemical Industries, Osaka, Japan). The cholesterol and TAG concentrations of lipoprotein fractions were determined enzymatically using a commercial kit (Cholesterol E-Test Wako and Triglyceride E-Test Wako). The total lipid content in the liver was determined gravimetrically after extraction using the method of Folch et al. ${ }^{(24)}$. The liver cholesterol and TAG concentrations were determined enzymatically, as described previously ${ }^{(25)}$.

The amount of bile acids in the small-intestinal contents and faeces was determined enzymatically using the $3 \alpha$-dehydrogenase assay method of Sheltaway \& Losowsky ${ }^{(26)}$, with taurocholic acid as a standard. Briefly, steroids were extracted from $50 \mathrm{mg}$ of small-intestinal contents and faeces with $5 \mathrm{ml}$ mixture of chloroform-methanol $(1: 1, \mathrm{v} / \mathrm{v})$ at $70^{\circ} \mathrm{C}$ for $60 \mathrm{~h}^{(27)}$. After extraction, the volume of the steroids solution was adjusted to $5 \mathrm{ml}$ with the same solution of chloroform-methanol (1:1, $\mathrm{v} / \mathrm{v})$. The extract $(1.5 \mathrm{ml})$ was dried under a $\mathrm{N}_{2}$ stream, and the residue obtained was mixed with $1 \mathrm{ml}$ methanol. This mixture $(10 \mu \mathrm{l})$ was mixed with $260 \mu \mathrm{l}$ of aqueous enzyme solution.

\section{RNA extraction from the liver and RT-PCR analysis of gene} expression

Total RNA was extracted from frozen livers according to the method described by Chomczynski \& Sacchi ${ }^{(28)}$. RNA integrity was verified by agarose gel electrophoresis after purification of mRNA with Oligotex-dT30 (Takara Bio, Shiga, Japan). Then, $1 \mu \mathrm{g}$ of mRNA was used for complementary DNA synthesis with 10 units of avian myeloblastosis virus (AMV) Reverse transcriptase (Takara Bio) and $2 \mu \mathrm{l}$ of oligo(dT) primer (Novagen, Inc., Madison, WI, USA) according to the manufacturer's instructions. Expression of mRNA for acyl-CoA:cholesterol acyltransferase 1, acyl-CoA:cholesterol acyltransferase 2, cholesterol 27-hydroxylase, cholesterol $12 \alpha$-hydroxylase, farnesoid $\mathrm{X}$ receptor, hydroxymethylglutaryl-CoA reductase, ileal bile acid transporter (IBAT), LDLreceptor, microsomal TAG transfer protein, sterol regulatory element-binding protein (SREBP)-1a, SREBP-1c, SREBP-2 and $\beta$-actin, as a housekeeping gene for normalisation, were determined by real-time monitoring of PCR using a Light Cycler instrument (Roche Diagnostics, Mannheim, Germany). Thereafter, $2 \mu \mathrm{l}$ of complementary DNA were amplified in a total volume of $20 \mu \mathrm{l}$ using the $2 \times$ QuantiTect SYBR Green RT-PCR Master Mix (Qiagen, Hilden, Germany) and specific primers each at $0.5 \mathrm{M}$. After initial denaturation and activation of the polymerase at $95^{\circ} \mathrm{C}$ for $15 \mathrm{~min}$, fifty cycles were performed with annealing temperatures for $25 \mathrm{~s}$, synthesis at $72^{\circ} \mathrm{C}$ for $30 \mathrm{~s}$ and denaturation at $94^{\circ} \mathrm{C}$ for $15 \mathrm{~s}$. Fluorescence was measured at the end of the elongation step at $72^{\circ} \mathrm{C}$. The sequences of the gene-specific primers (Carl Roth, Karlsruhe, Germany) used in the present study are listed in the Supplementary table (the supplementary material for this article can be found at http://www.journals.cambridge.org/bjn). Relative gene expression was calculated using the crossing point of each target gene; the $\beta$-actin gene was used as a reference.

\section{Statistical analyses}

Data are expressed as means with their standard errors. Data were analysed by one-way ANOVA using Super ANOVA (Abacus Concepts, Berkeley, CA, USA), and the differences among groups were examined by Tukey's multiple range test using the Super ANOVA statistical software package (Abacus Concepts) when the $F$ value was significant. A $P$ value $<0.05$ was considered significant.

Table 3. Effects of water-insoluble fish protein (IFP) and IFP + methionine (Met) on body-weight, body-weight gain, food intake, plasma lipids, and liver lipids in overiectomised (OVX) rats*

(Mean values with their standard errors, $n 6$ )

\begin{tabular}{|c|c|c|c|c|c|c|}
\hline & \multicolumn{6}{|c|}{ Diets } \\
\hline & \multicolumn{2}{|c|}{ Casein } & \multicolumn{2}{|c|}{ IFP } & \multicolumn{2}{|c|}{$\mathrm{IFP}+$ Met } \\
\hline & Mean & $\mathrm{SE}$ & Mean & SE & Mean & SE \\
\hline Body-weight gain ( $g / 28 d)$ & 39 & 4 & 35 & 3 & 45 & 3 \\
\hline Food intake $(\mathrm{g} / 28 \mathrm{~d})$ & 375 & 10 & 353 & 6 & 379 & 14 \\
\hline \multicolumn{7}{|l|}{ Plasma lipid (mmol//) } \\
\hline Cholesterol & $3.58^{\mathrm{b}}$ & 0.16 & $3.00^{\mathrm{a}}$ & 0.12 & $3.03^{a}$ & 0.11 \\
\hline TAG & 1.34 & 0.08 & 1.35 & 0.20 & 1.23 & 0.11 \\
\hline Liver weight (g) & $6 \cdot 90$ & 0.36 & $6 \cdot 15$ & 0.19 & $6 \cdot 60$ & 0.24 \\
\hline \multicolumn{7}{|l|}{ Liver lipid } \\
\hline Total lipids (mg/g liver) & 63.5 & $5 \cdot 8$ & $51 \cdot 2$ & 1.3 & $52 \cdot 1$ & $2 \cdot 7$ \\
\hline Cholesterol ( $\mu \mathrm{mol} / \mathrm{g}$ liver) & 14.9 & $1 \cdot 1$ & $15 \cdot 5$ & $2 \cdot 1$ & $17 \cdot 0$ & 1.9 \\
\hline $\mathrm{TAG}(\mu \mathrm{mol} / \mathrm{g}$ liver $)$ & $44 \cdot 6$ & $7 \cdot 7$ & $32 \cdot 3$ & $3 \cdot 2$ & $35 \cdot 3$ & 4.5 \\
\hline
\end{tabular}

a,b Mean values within a row with unlike superscript letters were significantly different $(P<0.05)$

* OVX rats were fed a test diet for $28 \mathrm{~d}$. 
Table 4. Effects of water-insoluble fish protein (IFP) and IFP + methionine (Met) on dry weights and bile acids of the small intestinal contents, mRNA levels of ileal bile acid transporter (IBAT) and faecal bile acid excretion in overiectomised (OVX) rats*

(Mean values with their standard errors, $n 6$ )

\begin{tabular}{|c|c|c|c|c|c|c|}
\hline & \multicolumn{6}{|c|}{ Diets } \\
\hline & \multicolumn{2}{|c|}{ Casein } & \multicolumn{2}{|c|}{ IFP } & \multicolumn{2}{|c|}{$\mathrm{IFP}+$ Met } \\
\hline & Mean & $\mathrm{SE}$ & Mean & SE & Mean & $\mathrm{SE}$ \\
\hline \multicolumn{7}{|l|}{ Small intestine } \\
\hline \multicolumn{7}{|l|}{ Intestinal contents } \\
\hline Dry weight (g) & 0.29 & 0.02 & 0.31 & 0.01 & 0.33 & 0.01 \\
\hline Bile acids ( $\mu \mathrm{mol})$ & $42 \cdot 6^{\mathrm{a}}$ & 3.0 & $61 \cdot 8^{\mathrm{b}}$ & 2.5 & $56 \cdot 3^{\mathrm{b}}$ & 1.7 \\
\hline IBAT mRNA (relative gene expression) & $1.40^{\mathrm{a}}$ & 0.22 & $0.72^{\mathrm{a}}$ & 0.13 & $1 \cdot 18^{\mathrm{a}, \mathrm{b}}$ & 0.15 \\
\hline \multicolumn{7}{|l|}{ Faecal excretion $\dagger$} \\
\hline Dry weight (g/d) & 0.62 & 0.06 & 0.60 & 0.06 & 0.56 & 0.08 \\
\hline Bile acids $(\mu \mathrm{mol} / \mathrm{d})$ & $15 \cdot 6^{\mathrm{a}}$ & 1.2 & $25 \cdot 1^{\mathrm{b}}$ & $2 \cdot 5$ & $22 \cdot 6^{a, b}$ & 2.5 \\
\hline
\end{tabular}

\section{Results}

Body-weight gain, food intake, plasma lipids and liver lipids

Body-weight gain and food intake were not affected by the diet (Table 3). The concentration of plasma cholesterol in rats fed the IFP and IFP + Met diets was significantly lower compared with OVX rats fed the casein diet. The concentration of plasma TAG was not affected by the diet. Liver weight and the concentration of total lipids and TAG in the liver were not affected by the diet.

\section{Intestinal contents and faecal excretion}

The dry weights of the small-intestinal contents and excreted faeces were not affected by the diet (Table 4). The amount of bile acids in the small-intestinal contents of OVX rats fed the IFP and IFP + Met diets was significantly higher compared with OVX rats fed the casein diet. The amount of bile acid excreted in the faeces was significantly higher in OVX rats fed the IFP diet compared with OVX rats fed the casein diet, but not in OVX rats fed the IFP + Met diet. The mRNA levels of IBAT were significantly lower in rats fed the IFP diet compared with rats fed the casein diet, but not in OVX rats fed the IFP + Met diet.

\section{Hepatic gene expression}

In the liver, the mRNA levels of cholesterol acyltransferase 1, cholesterol acyltransferase 2, cholesterol $7 \alpha$-hydroxylase, cholesterol $27 \alpha$-hydroxylase, farnesoid X receptor, hydroxymethylglutaryl-CoA reductase, LDL-receptor, liver $\mathrm{X}$ receptor, microsomal TAG transfer protein and SREBP-2 were not affected by the diet. When compared with OVX rats fed the casein diet, the mRNA levels of apo B and SREBP-1a were increased in OVX rats fed the IFP diet, but not in OVX rats fed the IFP + Met diet (Table 5). The mRNA levels of cholesterol $12 \alpha$-hydroxylase tended to be increased in rats fed the IFP diet compared with rats fed the casein and IFP + Met diets $(P=0.0632)$. The mRNA levels of SREBP-1c were higher in rats fed the IFP and IFP + Met diets.

\section{Discussion}

The concentration of plasma cholesterol was significantly lower in OVX rats fed the IFP and IFP + Met diets compared with OVX rats fed the casein diet. Because the diets did not contain cholesterol, it is clear that the hypocholesterolaemic effect of IFP in the OVX rats must be due to changes in endogenous sterol metabolism.

Table 5. Effects of water-insoluble fish protein (IFP) and IFP + methionine (Met) on hepatic mRNA levels in overiectomised (OVX) rats* (Mean values with their standard errors, $n 6$ )

\begin{tabular}{|c|c|c|c|c|c|c|}
\hline \multirow[b]{3}{*}{ Genes† } & \multicolumn{6}{|c|}{ Diets (arbitary units) } \\
\hline & \multicolumn{2}{|c|}{ Casein } & \multicolumn{2}{|c|}{ IFP } & \multicolumn{2}{|c|}{ IFP + Met } \\
\hline & Mean & SE & Mean & SE & Mean & SE \\
\hline ACAT1 & 0.90 & 0.03 & 1.03 & 0.06 & 0.92 & 0.04 \\
\hline АCAT2 & 0.85 & 0.04 & 0.78 & 0.08 & 0.76 & 0.08 \\
\hline ApoB & $0 \cdot 14^{\mathrm{a}}$ & 0.02 & $0.33^{\mathrm{b}}$ & 0.05 & $0.29^{a, b}$ & 0.05 \\
\hline CYP7A1 & 0.50 & $0 \cdot 10$ & 0.82 & $0 \cdot 16$ & 0.46 & 0.05 \\
\hline CYP8B1 & 0.46 & 0.07 & 0.72 & $0 \cdot 12$ & 0.41 & 0.06 \\
\hline CYP27A1 & 1.09 & 0.05 & 1.20 & 0.08 & 1.24 & 0.13 \\
\hline FXR & 0.68 & 0.04 & 0.72 & 0.04 & 0.67 & 0.04 \\
\hline HMG-CoA R & 0.38 & 0.04 & 0.28 & 0.04 & 0.31 & 0.06 \\
\hline LDL-R & 0.35 & 0.07 & 0.31 & 0.02 & 0.30 & 0.02 \\
\hline LXR & 1.01 & 0.06 & 0.97 & 0.07 & 0.99 & 0.06 \\
\hline MTP & 0.48 & 0.02 & 0.50 & 0.04 & 0.51 & 0.02 \\
\hline SREBP-1a & $0.44^{\mathrm{a}}$ & 0.07 & $0.76^{\mathrm{b}}$ & $0 \cdot 10$ & $0.69^{a, b}$ & 0.08 \\
\hline SREBP-1C & $0.80^{\mathrm{a}}$ & $0 \cdot 17$ & $1.79^{b}$ & 0.35 & $1.79^{\mathrm{a}}$ & 0.31 \\
\hline SREBP-2 & 0.09 & 0.02 & 0.12 & 0.01 & 0.13 & 0.02 \\
\hline
\end{tabular}

ACAT, acyl-CoA:cholesterol acyltransferase; CYP7A1, cholesterol $7 \alpha$-hydroxylase; CYP8B1, cholesterol 12 $\alpha$-hydroxylase; CYP27A1, cholesterol 27-hydroxylase; FXR, farnesoid X receptor; HMG-CoA, hydroxymethylglutaryl-CoA; LDL-R, LDL-receptor; LXR, liver $X$ receptor; MTP, microsomal TAG transfer protein; SREBP, sterol regulatory element-binding protein.

${ }^{a, b}$ Mean values within a row with unlike superscript letters were significantly different $(P<0.05)$.

* OVX rats were fed a test diet for $28 \mathrm{~d}$.

† See the supplymentary table (the supplementary material for this article can be found at http://www.journals.cambridge.org/bjn). 
Although the mechanism of the hypocholesterolaemic effect of fish proteins is not yet fully understood, a potential explanation for the cholesterol-lowering effect may lie in their amino acid profiles ${ }^{(29)}$. Met was shown to elevate serum cholesterol concentration ${ }^{(30)}$. The hypocholesterolaemic effects of soya protein, potato protein and rice in rats depend on their low Met content ${ }^{(19)}$. The Met content in the IFP diet was about half of that in the casein diet. However, in the present study, the hypocholesterolaemic effect of the IFP diet was not abolished by the addition of Met. Morita et $a l .{ }^{(19)}$ have reported that the higher ratio of Met:glycine in casein may be responsible for elevations in serum cholesterol. The ratios of Met:glycine (w/w) in the IFP and IFP + Met diets ( 0.38 and 0.76 , respectively) were lower compared with the casein diet (1.22). Therefore, it seems that the amino acid profile, in part, linked to the hypocholesterolaemic effect of IFP.

Changes in amino acid metabolism after ovariectomy might affect cholesterol metabolism. After ovariectomy, serum alanine was significantly decreased in contrast to serum glycine and branched-chain amino acids; however, amino acid metabolism per se had not any significant link to cholesterol metabolism in OVX rats ${ }^{(31)}$.

An increased faecal excretion of bile acids is considered a factor in the hypocholesterolaemic effect of IFP. The primary bile acids produced in the liver are usually converted into either glycine- or taurine-conjugated bile acids before excretion into the bile. The active uptake of conjugated bile acids from the small intestine is mediated by IBAT located on the apical membrane of the ileal enterocyte ${ }^{(32)}$. The mRNA levels of IBAT were significantly lower in OVX rats fed the IFP diet compared with OVX rats fed the casein diet. In addition, the amount of bile acids in the small intestine and faecal excretion of bile acids were significantly higher in OVX rats fed the IFP diet compared with OVX rats fed the casein diet, which suggests that IFP might inhibit the ileal reabsorption of bile acids through decreased IBAT. The amount of bile acids in the small-intestinal content and the amount of bile acids excreted into faeces were significantly higher $(P=0.0491)$ in OVX rats fed the IFP + Met diet compared with OVX rats fed the casein diet; however, the mRNA levels of IBAT were not significantly different. The levels of hepatic cholesterol $7 \alpha$-hydroxylase mRNA were not affected by the diet; however, there was a positive correlation between faecal excretion of bile acids and the levels of hepatic cholesterol $7 \alpha$-hydroxylase mRNA ( $r$ 0.557, $P=0.0164)$. The undigested fraction of soya protein can bind bile acids, in particular conjugated bile salts, and increase faecal excretion of bile acids in rats ${ }^{(33)}$. IFP may be able to bind bile acids. Therefore, an increased faecal excretion of bile acids by feeding the IFP diet might depend on decreased reabsorption due to bile acid binding of the undigested fraction of IFP rather than on decreased reabsorption of bile acids from the ileum by a decrease in IBAT.

Fatty acid synthase expression is increased by SREBP-1c activation $^{(34,35)}$. Fatty acids are the major components of TAG. The levels of SREBP-1c mRNA were significantly higher in OVX rats fed the IFP and IFP + Met diets compared with OVX rats fed the casein diet; however, total lipids in the liver of OVX rats fed the IFP and IFP + Met diets tended to be lower compared with OVX rats fed the casein diet $(P=0.0672)$. The concentration of TAG in the liver was not affected by the diet. It is not known why the TAG concentration in the liver was not affected by the diet.

In conclusion, plasma total cholesterol concentration decreased in OVX rats fed the IFP diet compared with OVX rats fed the casein diet, and the hypocholesterolaemic effect of the IFP diet was not abolished by Met addition to the IFP diet. The hypocholesterolaemic effect of IFP in OVX rats may be mediated by increased faecal excretion of bile acids coupled with decreased reabsorption of bile acids from the ileum through a decrease in IBAT and by the change in cholesterol metabolism linked to the amino acid profile. However, mRNA expression level is necessarily reflecting neither activity nor the amount of proteins. Therefore, there would be a limit in clarifying the mechanism of a hypocholesterolaemic effect of IFP by the change in the mRNA expression level of genes that relate to cholesterol metabolism. Further studies to clarify the hypocholesterolaemic effect of IFP in OVX rats are needed.

\section{Acknowledgements}

The present study was supported, in part, by the All-Japan Kamaboko Makers Association Grant Research. There are no conflicts of interest on the present study. The present study was supported by the grant of the All-Japan Kamaboko Makers Association. The contribution of each author to the manuscript is as follows: M. K. carried out the experimental plan, summarised the experimental results and discussed the experimental results with the other researchers. H. O. advised on all aspects of the experiment and discussed the experimental results. T. K. advised on all aspects of the experiment. K. E. designed the experiment and was involved in the manuscript preparation.

\section{References}

1. Gevers Leuven JA (1994) Sex steroids and lipoprotein metabolism. Pharmacol Ther 64, 99-126.

2. Shono N, Kumagai S \& Sasaki H (1996) Obesity, glucose and lipid metabolism, and steroid hormones. J Health Sci 18, 21-44 (In Japanese).

3. Sullivan TR Jr, Karas RH, Aronovitz M, et al. (1995) Estrogen inhibits the response-to-injury in a mouse carotid artery model. J Clin Invest 96, 2482-2488.

4. Chen SJ, Li H, Durand J, et al. (1996) Estrogen reduces myointimal proliferation after balloon injury of rat carotid artery. Circulation 93, 577-584.

5. Colditz GA, Willett WC, Stampfer MJ, et al. (1987) Reproducibility and validity of self-reported menopausal status in a prospective cohort study. Am J Epidemiol 126, 319-325.

6. Rosano GM \& Fini M (2002) Postmenopausal women and cardiovascular risk: impact of hormone replacement therapy. Cardiol Rev 10, 51-60.

7. Judd HL, Meldrum DR, Deftos LJ, et al. (1983) Estrogen replacement therapy: indications and complications. Ann Intern Med 98, 195-205. 
8. Henderson BE, Ross RK \& Pike MC (1993) Hormonal chemoprevention of cancer in women. Science 259, 633-638.

9. Kritchevsky D (1995) Dietary protein, cholesterol and atherosclerosis: a review of the early history. $J$ Nutr $\mathbf{1 2 5}$, 589S-593S.

10. Kris-Etherton PM, Harris WS \& Appel LJ (2002) Fish consumption, fish oil, omega- 3 fatty acids, and cardiovascular disease. Circulation 106, 2747-2757.

11. Zhang X \& Beynen AC (1993) Influence of dietary fish proteins on plasma and liver cholesterol concentrations in rats. Br J Nutr 69, 767-777.

12. Wergedahl H, Liaset B, Gudbrandsen OA, et al. (2004) Fish protein hydrolysate reduces plasma total cholesterol, increases the proportion of HDL cholesterol, and lowers acyl-CoA:cholesterol acyltransferase activity in liver of Zucker rats. J Nutr 134, 1320-1327.

13. Shukla A, Bettzieche A, Hirche F, et al. (2006) Dietary fish protein alters blood lipid concentrations and hepatic genes involved in cholesterol homeostasis in the rat model. $\mathrm{Br} \mathrm{J}$ Nutr 96, 674-682.

14. Spielmann J, Kluge H, Stangl GI, et al. (2008) Hypolipidaemic effects of potato protein and fish protein in pigs. $J$ Anim Physiol Anim Nutr (Berl) 93, 300-409.

15. Potter SM (1995) Overview of proposed mechanisms for the hypocholesterolemic effect of soy. J Nutr 125, Suppl. 3, 606S-611S

16. Shukla A, Brandsch C, Bettzieche A, et al. (2007) Isoflavonepoor soy protein alters the lipid metabolism of rats by SREBP-mediated down-regulation of hepatic genes. $J$ Nutr Biochem 18, 313-321.

17. Oda $\mathrm{H}$ (2006) Function of sulfur-containing amino acids in lipid metabolism. J Nutr 136, 1666S-1669S.

18. Sugiyama K, Kanamori H, Akechi T, et al. (1996) Amino acid composition of dietary protein affects plasma cholesterol concentration through alteration of hepatic phospholipids metabolism in rats fed a cholesterol-free diet. J Nutr Biochem 7, $40-48$

19. Morita T, Oh-hashi A, Takei K, et al. (1997) Cholesterollowering effects of soybean, potato, and rice proteins depend on their low methionine contents in rats fed a cholesterol-free purified diet. J Nutr 127, 470-477.

20. Kato M, Ogawa H, Kishida T, et al. (2009) The mechanism of the cholesterol-lowering effect of a water-insoluble fish protein in ovariectomized rats. Br J Nutr 102, 816-824.

21. Reeves PG, Nielsen FH \& Fahey GC (1993) AIN-93 purified diets for laboratory rodents: final report of the American Institute of the Nutrition $A d$ hoc Writing Committee on the
Reformulation of AIN-76A Rodent Diet. I Nutr 123, $1939-1951$.

22. National Research Council (1995) Nutrient Requirement of the laboratory rat. In Nutrient Requirements of Laboratory Animals, 4th rev. ed., pp. 11-79. Washington, DC: National Academy of Sciences.

23. Hasegawa T \& Kuroda M (1990) Automated amino acids determination. Med Technol 18, 121-127.

24. Folch J, Lees M \& Sloane Stanley GH (1957) A simple method for the isolation and purification of total lipides from animal tissue. J Biol Chem 226, 497-509.

25. Ebihara K, Shiraishi R \& Okuma K (1998) Hydroxypropylmodified potato starch increases fecal bile acid excretion in rats. I Nutr 128, 848-854.

26. Sheltaway MJ \& Losowsky MS (1975) Determination of fecal bile acids by an enzymic method. Clin Chem Acta 64, 127-132.

27. Eneroth P, Hellstrom K \& Sjovall J (1968) A method for quantitative determination of bile acids in human feces. Acta Chem Scand 22, 1729-1744.

28. Chomczynski P \& Sacchi N (1987) Single-step method of RNA isolation by acid guanidinium thiocyanate-phenolchloroform extraction. Anal Biochem 162, 156-159.

29. Sugano M, Ishiwaki N \& Nakashima K (1984) Dietary protein-dependent modification of serum cholesterol level in rats. Ann Nutr Metab 28, 192-199.

30. Sugiyama K, Ohkawa S \& Muramatsu K (1986) Relationship between amino acid composition of diet and plasma cholesterol level in growing rats fed a high cholesterol diet. J Nutr Sci Vitaminol 32, 413-423.

31. Frauscher G \& Lubec G (1994) The effect of ovariectomy of serum amino acids and cholesterol in the rat. Amino Acids $\mathbf{6}$, $37-45$.

32. Wong MH, Oelkers P, Craddock AL, et al. (1994) Expression cloning and characterization of the hamster ileal sodiumdependent bile acid transporter. J Biol Chem 269, $1340-1347$.

33. Sugano M, Goto S, Yamada Y, et al. (1990) Cholesterollowering activity of various undigested fractions of soybean protein in rats. J Nutr 120, 977-985.

34. Swinnen JV, Ulrix W, Henys W, et al. (1997) Coordinate regulation of lipogenic gene expression by androgens: evidence for a cascade mechanism involving sterol regulatory element binding proteins. Proc Natl Acad Sci U S A 94, 12975-12980.

35. Bennett MK, Lopez JM, Sanchez HB, et al. (1995) Sterol regulation of fatty acid synthase promoter. Coordinate feedback regulation of two major lipid pathways. J Biol Chem 270, $25578-25583$ 